\title{
CONSUMPTION BEHAVIOUR OF FARMER HOUSEHOLDS IN RURAL SUMBAWA, INDONESIA
}

\author{
Budiman Achmad* and Dian Diniyati \\ Agroforestry Technology Research Institute, \\ Jl. Raya Ciamis - Banjar Km. 4, Ciamis 46201, West Java, Indonesia
}

Received: 20 January 2018, Revised: 30 April 2018, Accepted: 30 April 2018

CONSUMPTION BEHAVIOUR OF FARMER HOUSEHOLDS IN RURAL SUMBAWA, INDONESIA. The welfare level of farmer in rural Sumbawa was steadily low although the potency of natural resources at their vicinity was high. This paper determines the consumption behaviour as well as the welfare level of farmer households in rural Sumbawa, Indonesia. The household size, years of education, and farming incomes were used as indicators of on-farm performance. This research was carried out in February until April 2015 at two separate forest areas which were administratively under Labuhan Badas village, i.e. community forestry $(\mathrm{HKm})$ in the state production forest and private owned forests (POF). A number of 34 respondents per location were purposively selected. The multiple linear regression was implemented to analyze factors affecting farmer household consumption behaviour, while the exchange value for income earned by farmer (EVIF) was incorporated to measure the welfare level. The regression revealed that the consumption behaviour at two groups of respondents were positively related with three indicators, i.e. household size, years of education, and farming incomes. Meanwhile, the household size affected the consumption behaviour of the HKm farmers but not the POF farmers. Furthermore, the consumption is strongly affected by the income generated from both forest areas. The EVIF approach revealed that the welfare of whole farmers were still low (EVIF $=0.74-0.99)$. The government, therefore, should subsidize rain fed paddy and tobacco seeds varieties which are suitable with the local climate, while the farmers are trained to process the flesh of cashew fruit into wine or chips and encouraged to cultivate calliandra trees for apiculture development and wood pellet or charcoal production.

Keywords: Farmers, on-farm performance, private owned forest, state forest, welfare

POLA KONSUMSI RUMAH TANGGA PETANI DI PEDESAAN SUMBAWA, INDONESLA. Tingkat kesejabteraan petani di pedesaan Sumbawa tetap rendah meskipun potensi sumberdaya alam di sekitar mereka tinggi. Penelitian ini mempelajari faktor-faktor yang mempengarubi pola konsumsi dan tingkat kesejabteraan petani pedesaan Sumbawa, Indonesia. Ukuran rumah tangga, lamanya pendidikan, dan pendapatan dari usaha tani digunakan sebagai indikator dari kinerja lahan pertanian. Penelitian ini dilakukan pada bulan Februari sampai April 2015 pada dua areal butan yang terpisah dimana secara administrasi berada dalam Desa Labuban Badas yaitu: butan kemasyarakatan (HKm) di dalam area butan produksi negara dan butan milik. (HR). Di tiap lokasi, sebanyak, 34 responden dipilih secara sengaja. Analisis multilinear regresi digunakan untuk menganalisis faktor-faktor yang mempengarubi pola konsumsi, sementara itu nilai tukar pendapatan rumah tangga petani (NTPRP) digunakan untuk. mengukur tingkat kesejabteraan. Regresi mengungkap bahwa pola konsumsi petani di dua areal butan berkorelasi positif dengan ketiga indikator. Sementara itu, ukuran rumah tangga mempengarubi pola konsumsi petani di HKm, tetapi tidak di HR. Selanjutnya, pola konsumsi dipengarubi oleh pendapatan usaha tani di kedua areal butan. Melalui pendekatan NTPRP diketabui bahwa tingkat pendapatan selurub petani masib rendah (NTPRP =0,74-0,99). Oleh karena itu pemerintah sebaiknya mensubsidi bibit padi tadah hujan dan bibit tembakan yang varietasnya sesuai dengan iklim setempat, sementara itu petaniya sebaiknya dilatih untuk. mengolah daging buah jambu mete menjadi anggur dan kripik, didorong menanam pohon kaliandra untuk. pakan lebah madu dan bahan pembuatan pelet kayu atau arang.

Kata kunci: Petani, kinerja lahan pertanian, butan milik, hutan negara, kesejabteraan

*Corresponding author: budah59@y yahoo.com 


\section{INTRODUCTION}

The behaviour of consumption could reflect more realistic depiction about farmer welfare levels (Larsen, 2007; Ibragimov, Ismagilov, \& Molotov, 2014), as by scrutinizing those patterns it could be indicated what kind and amount of consumption they would perform. Until recently, poverty still becomes the major issue for rural communities in Indonesia. Like other places in Indonesia, Sumbawa also has strength and weaknesses in terms of natural resources potency. This island is even being famous with their specific non-timber forest products (NTFPs) such as bee's honey and cashew nuts. However, the income of forest farmers in rural Sumbawa was steadily low.

Food consumption behaviour of forest farmers in Indonesia was less ideal since farmers consumed only more rice than other carbohydrate sources to meet their nutrition need (Damora et al., 2008). This fact makes the government programme to reach food security goal in Indonesia is more difficult. They even like to spent more money to consume less healthy goods such as tobacco. The amount of income earned by particular households which was further spent on food items could be used as a reliable indicator to estimate their welfare. The greater the expenses of particular households for food consumption, the lower would be their welfare level, and vice versa (Purwantini, 2012).

The income level of surrounding forest community who managed the state production forest at Labuhan Badas village was suspected lower than the income level of the farmers who managed their private owned forest. This was due to the regulation for the state forest management which was more complicated than the ones for the private owned forest. In the state forest area, under specific regulation named community-based forest management (CBFM) which control some conditions such as tree composition, pattern of plantation, time of harvesting and forest yields sharing, the community-based forest $(\mathrm{HKm})$ farmers received limited right and access in cultivating the land. Based on the rule, the HKm farmers must cultivate the land with vegetation ratio of 50\%: 30\%: 20\% between trees: multipurpose tree species (MPTS): cash crops, respectively. Furthermore, the $\mathrm{HKm}$ farmers are not permitted to harvest trees before harvesting time, except the fruits from MPTS plants and cash crops. The situation was different for the private owned forest where farmers are able to harvest their forest products at any time they need. The low income of HKm farmers makes them very vulnerable falling into middlemen traps. Under middlemen control, their bargaining position is very low resulting lower farmer's annual income. Consequently, the welfare level of $\mathrm{HKm}$ farmers as well as the quality of forest environment is getting worse.

The amount of household consumption was affected by several factors, which comprised: income of household, household size, years of education (Kedir \& Sookram, 2011), as well as, and availability of goods consumed (Hupkova et al., 2009). Those factors would affect the behaviour of consumption at different intensity. With those limiting factors, it prompts the farmers to make the best decision in order to fulfil their household's needs. By having information about consumption behaviour, the threat to the farmer's economy and the degradation of the environment could be anticipated earlier and therefore some solutions could be prepared.

Evidence has showed that HKm poverty could be successfully combated by implementing appropriate management programmes such as the HKm farmers in Lampung who could reach the prosperous level (Yulian et al., 2016). This fact encourages us to explore the determinants of consumption behaviour of $\mathrm{HKm}$ farmers at Labuhan Badas village in order to improve their welfare level as well as the environmental quality. This paper studies consumption behaviour of farmer households in rural Sumbawa, together with the assessment on the possible factors that might affect those behaviour. 


\section{MATERIAL AND METHOD}

\section{A. Site Description}

The study was conducted at two separate forest areas, i.e. 1) the community forestry $(\mathrm{HKm})$ in the state production forest, and 2) the private owned forests (POF) nearby the state production forest. Both of them were administratively under Labuhan Badas village (080 47.244' S, 1170 32.959’ E), Sumbawa Regency (Figure 1). The study was carried out in February until April 2015.

The state production forest areas have been occupied by people originated from Lombok who inhabited the area to practice agroforestry system by cultivating teak, mahagony, maize, rice, sesame seeds, soybeans, green peas, and pigeon peas. They manage the state forest under a special regulation namely the communitybased forest management (CBFM) issued by the local government authority (Dinas Kehutanan dan Perkebunan Kabupaten Sumbawa), and then they were called as HKm farmers. Some of the $\mathrm{HKm}$ farmers periodically migrate to Lombok to visit their hometown or to search other additional incomes.
Meanwhile, the private owned forest area was resided by land owners (local people) who were also practised agroforestry system; they were called private owned forest (POF) farmers. They manage their own forest without any strict regulation from elsewhere. They freely cultivate any species of plants such as teak, mahagony, cashew, maize, rice, green peas and pigeon peas and harvest them whenever they need.

The cashew trees were found almost at any block of the both forests areas $(\mathrm{HKm}$ and POF). However, the farmers have not utilized the whole part of the fruit yet, but the nuts. Until recently, the flesh of fruit have not been consumed or processed become other valuable products, but just left become waste.

\section{B. Methods}

The samples comprised farmers who resided at the area of Labuhan Badas village. The respondents were categorized into two groups, namely (1) the HKm farmers, who performed agroforestry practise at the state forest; and (2) the POF farmers, who performed agroforestry at their own land. The total of 68 farmers from those two groups were selected by performing

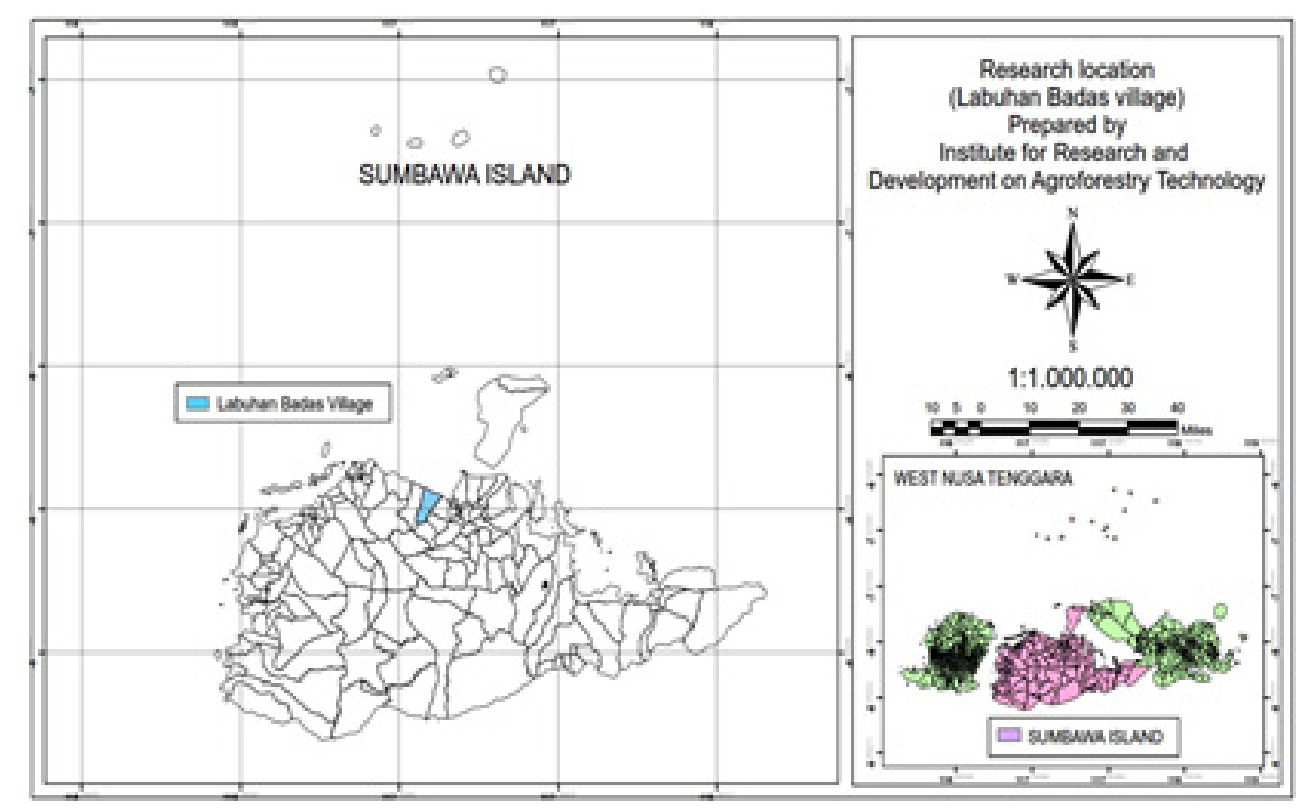

Figure 1. The research location (Labuhan Badas village) which administratively covers the HKm (in the state production forest) and the private owned forests (the POF) 
the purposive sampling (Sugiyono., 2013). To become respondents, the farmers should meet some following criterias: a) being a member of the farmer group and practising agroforestry, b) understand the problems related with their plants, and c) cooperative. The number of respondents taken from each group (items 1 and 2) was equal (i.e. 34 farmers).

The primary data were obtained by performing interview and the focus group discussion (FGD) techniques, which were likely performed at qualitative and quantitative research approaches (Morgan \& Harmon, 2001). Type of data consisted of (1) food and nonfood consumptions, (2) years of education of the households head, (3) households size and (4) amount of income earned by households. The obtained data were grouped, commensurated with the research aims, tabulated and further analysed.

\section{Analysis}

The descriptive analysis was employed to provide a reliable illustration about the patterns of consumption spent by farmer households. The results would bring out information about the farmer consumption behaviour as well as the attempt that should be carried out by farmers to meet their consumption needs and the incentives associated with the aid strategies that should be provided by government.

The multiple linear regression (MLR) was implemented to examine the factors affecting the consumption behaviour by farmer households. In this method, the expenses for the consumption of food and non-food items - in IDR/year $(Y)$ by farmer household was hypothesised to be influenced by household size - in persons $\left(X_{1}\right)$, years of education of the households head - in years $\left(X_{2}\right)$, and annual income - in IDR $\left(X_{3}\right)$. The general formula for MLR equation with regard to the consumption behaviour $Y=\mathrm{f}\left(X_{1}, X_{2}, X_{3}\right)$ together with the coefficient of determination $\left(R^{2}\right)$ (Equation 1 and 2) were as follows (Misbahuddin \& Hasan, 2013):

$$
Y=\alpha+b_{1} X_{1}+b_{2} X_{2}+b_{3} X_{3}+\varepsilon
$$

$$
R^{2}=\frac{S S R}{S S T}
$$

where:

$\mathrm{R}^{2}=$ coefficient of determination; $\mathrm{SSR}=$ Sum square of regression; $\mathrm{SST}=$ Sum squares of total

The analysis was performed using the software package SPSS 13.0.

The quantitative analysis was also employed to analyse the welfare levels of farmer's household. The criteria regarding such welfares were modified from the Parity Ratio developed by Tomek and Kaiser (2014), using the quantitative measure of the so-called exchange value for the income of farmer households (EVIF). The EVIF value as such implied the capability measurement of farmer households in satisfying their subsistence needs. The EVIF value represented the ratio between total incomes and total expenses of households. Meanwhile, total incomes of farmer households referred to the summation results of all values generated from on-farm works (e.g. dry farming, farm worker, cattle raiser and off-farm works (e.g. stone/sand searcher, assistant, truck driver, trader, building laborer, employees, delivery from spouse or children). On the other hand, the expenses spent by farmers were the summation of their expenses for household consumption and their expenses for production costs. The EVIF was measured by calculating incomes earned from agriculture efforts $\left(Y_{p}\right)$, plus incomes earned from nonagriculture efforts $\left(Y_{\mathrm{np}}\right)$, divided by expenses for agriculture efforts $\left(E_{p}\right)$ plus expenses for non-agriculture efforts $\left(E_{\mathrm{np}}\right)$ as performed in Equation 3.

$$
E V I F=\frac{\left[Y_{p}+Y_{n p}\right]}{\left[E_{p}+E_{n p}\right]}
$$

The decision criteria are as follows: if the EVIF value was greater than one, it would imply that the welfare level of households belonged to a prosperous category. Conversely, if the EVIF value less than one, it would indicate that the household welfare was still not regarded as prosperous category (Yulian et al., 
2016). Furthermore, t-test was implemented to evaluate the difference on annual total consumption between the HKm farmers and the POF farmers. The analysis was performed using the software package SPSS 13.0.

\section{III.RESULT AND DISCUSSION}

\section{A. Expense for Consumption}

The expense spent by households could reflect their consumption pattern and figured out their welfare level. The structure of expense by farmer households consisted of three types, covering expenses for food, non-food items (e.g. clothing, school fees, house repair, health) and fuels. The greatest amount of expense for food was for cereal consumption (especially rice), which in portion reached consecutively $53.62 \%$ (by the HKm farmers) and 36.83\% (by the POF farmers). This indicated that the $\mathrm{HKm}$ farmers were still at the level of satisfying their basic needs for their life, while the rest of their expenses were used to meet consecutively the non-food and fuel consumptions. This situation was commensurated with the particular research conducted by Randy, Rudi, and Herwanti (2016) in Sumber Agung village which inferred that the necessity levels for food by farmers were greater than those for nonfood items.

Income level of farmer households influenced the choice on food to be consumed (Sosa et al., 2015). The households with low income would rather consume food with more varying composition (Drewnowski \& Specter, 2004; Zentková \& Hošková, 2011a), while the households with middle-up income preferred to choose less varying food (Pusposari, 2012). It means that households with low income usually more tolerate in consuming any kind of junk food as well as tradisional food. Nonetheless, all those cases apparently did not apply to the research location, in this regard, although the income level of the HKm farmers was low, they preferred consuming rice. The main reason was, as the limiting factor, the natural condition did not allow the land to be cultivated with alternative-food crops. Consequently, no other choices but rice become their main food.

Tobacco consumed by the HKm farmers was the second biggest expense after rice, which in portion corresponded to $12.17 \%$. However, for the POF farmers, the portion was smaller $(10.36 \%)$. That expense closely related to the health awareness indicated by the portion of health expense was only $4.82 \%$ (for the HKm farmers). Tobacco smoking was not only an expensive behaviour but also lead to broader impact on the wellbeing of smokers with limited financial resources (Widome et al., 2015). However, the HKm farmers seemed did not consider those. However, such high tobacco consumption was not associated with lower level of happiness or higher level of depression as investigated by Churchill and Farrell (2017), but it was attributed to the preparation activities for the planting season. The cigarettes were needed to neutralize the cool air blowing during the activities for land cultivation.

The expense for health maintenance by the $\mathrm{HKm}$ household was very limited; it was IDR 177,600 per year or $4.82 \%$ of non-food items need. This expense was even less than half portion for health maintenance by the POF farmers which reached $10.73 \%$. The $\mathrm{HKm}$ farmers preferred to take traditional medicines instead, that flourished abundantly in the nature. They would only visit the physician, if their sickness persisted and could no longer be cured by traditional medicines. It might relate to Srivastava and McGuire (2015) statement that low-income patients would experience access problems, raising important policy implications to improve access to health care and medicines.

The clothing necessities for the POF farmers were mostly provided by their relatives and their children. This made the expenditure for clothing of the POF farmers was relatively small. Conversely, the expenditure for children education was quite high as both farmer groups unexpected their children to experience the living situation like them.

Nearly all activities of the farmers were performed using gasoline-powered two- 
Table 1. Average amount of expenses for the consumption of food, non-food, and fuel items by farmer household per year

\begin{tabular}{|c|c|c|c|c|}
\hline \multirow{3}{*}{ Group of items as consumed } & \multicolumn{4}{|c|}{ Farmers } \\
\hline & \multicolumn{2}{|c|}{$\mathrm{HKm}$} & \multicolumn{2}{|c|}{ POF } \\
\hline & $\begin{array}{c}\text { Amount } \\
\text { (IDR) }\end{array}$ & $(\%)$ & $\begin{array}{c}\text { Amount } \\
\text { (IDR) }\end{array}$ & $(\%)$ \\
\hline \multicolumn{5}{|l|}{ A. Kinds of food items as consumed } \\
\hline 1. Rice & $3,780,000$ & 53.62 & $4,310,000$ & 36.83 \\
\hline 2. Animal Protein & 792,000 & 11.23 & $1,910,000$ & 16.32 \\
\hline 3. Vegetation protein & 168,000 & 2.38 & $1,470,000$ & 12.56 \\
\hline 4. Vegetables + fruit & 564,000 & 8.00 & 990,000 & 8.46 \\
\hline 5. Oil + fat & 300,000 & 4.26 & 445,000 & 3.80 \\
\hline 6. Beverages & 252,000 & 3.57 & 813,000 & 6.95 \\
\hline 7. Spices & 240,000 & 3.40 & 400,000 & 3.42 \\
\hline 8. Ready-consumed food & 96,000 & 1.36 & 152,000 & 1.30 \\
\hline 9. Tobacco & 858,000 & 12.17 & $1,213,000$ & 10.36 \\
\hline Sub-total A & $7,050,000$ & 100.00 & $11,703,000$ & 100.00 \\
\hline \multicolumn{5}{|l|}{ B. Kinds of non-food items as consumed } \\
\hline 1. Education & $1,572,000$ & 42.70 & $1,812,000$ & 40.12 \\
\hline 2. House repair & 690,000 & 18.74 & 888,000 & 19.66 \\
\hline 3. Clothing & 396,000 & 10.76 & 288,000 & 6.38 \\
\hline 4. Health & 177,600 & 4.82 & 484,800 & 10.73 \\
\hline 5. Others & 846,000 & 22.98 & $1,044,000$ & 23.11 \\
\hline Sub-total B & $3,681,600$ & 100.00 & $4,516,800$ & 100.00 \\
\hline \multicolumn{5}{|l|}{ C. Kinds of fuels as consumed } \\
\hline 1. Gasoline & 431,000 & 67.55 & 286,000 & 50.18 \\
\hline 2. Kerosene & 207,000 & 32.45 & 284,000 & 49.82 \\
\hline Sub-total C & 638,000 & 100.00 & 570,000 & 100.00 \\
\hline Total $(A+B+C)$ & $11,369,600$ & 100.00 & $16,789,800$ & 100.00 \\
\hline
\end{tabular}

cycle vehicles due to the absence of public transportations. The expenditure by the HKm farmers on gasoline was about double than kerosene, while that expenditure by the POF farmers was almost similar. This difference occurred since the total distance of farm land that should be controlled by the HKm farmers was more remote than the farm land belonged to the POF farmers. Besides that, fire woods at the $\mathrm{HKm}$ forest were more abundant so that they could replace partial consumption of the kerosene. Unlike the $\mathrm{HKm}$ farmers, the POF farmers were able to process coconut fruits into the frying oil for complying with their cooking needs, thereby not only allowing them to cut down expenses, but also earning higher additional incomes. According to Ningsih, Suandi, and Damayanti (2012), the greater the income level of a person, the greater as well would be the consumption level. Their statement was commensurate with the condition of farmers at the research location, although the portions of the type of food consumed were different. In this case, the greater income of a person, the more they would abandon in rice purchasing. Crawford, Laisney, and Preston (2003) argued that the higher welfare of a person, the lower they would consume food stuffs; but the greater they would expend on luxurious and high-technology items).

Total expense of the HKm farmer household for consumption was smaller than that of the 
POF farmer household. This condition was inline with Foss (2014) statement that HKm activities were often established in marginal or highly degraded areas and most of their incomes were for subsistence. Moreover, enforcement of implementation rules in $\mathrm{HKm}$ agreement i.e. designing plants composition and timber harvesting schedule tended to limit access to forest products harvesting. According to $\mathrm{Hkm}$ agreement, the composition of $50 \%$ woody trees, 30\% multipurpose tree species (MPTS) and $20 \%$ cash crops should be employed and farmers were not allowed to cut the trees before the harvesting time. Those all constraints have caused the incomes of $\mathrm{HKm}$ farmers remained low which lead to low expenditure as well.

\section{B. Determinants of Consumption Behaviour}

The following three factors i.e. household size $\left(X_{1}\right)$, years of education $\left(X_{2}\right)$, and the income $\left(X_{3}\right)$ impacted almost equally on the household consumption expenditure $(Y)$ both for $\mathrm{HKm}$ and POF farmers Table 2.

Based on the MLR analysis, the consumption by the HKm household (Y) of $67.08 \%$ could be explained by household size (X1), years of education (X2), and annual income (X3); while the rest of it $(32.92 \%)$ was due to unexplainable factors, which were regarded as errors. Likewise, the corresponding figures for the POF farmers were consecutively $70.39 \%$ (as explained by those three factors) and the rest of it (29.61\%) were due to unexplainable factors).

The annual income became the most dominant factor affected farmer households consumption expenditure. Therefore, it was confirmed that relationship between the income and the consumption belonged to strong category, under the situation where the effect of household size and years of education were assumed to be constant. On the other hand, effect of years of education on household consumption seemed to be the weakest. Therefore, the relationship between years of education and consumption for both farmer groups belonged to very weak category.

Similarly, the effect of household size on the consumption for the POF farmers was far weaker than for the HKm farmers despite both revealing a positive relationship. This weak effect was due to the good items which should be compensated by household especially food consisted of shared items as also reported by Jacobson et al., (2010). However, the way of how the household size affected the equally consumption for the HKm farmers appeared to be rather different from the way for the POF farmers.

Based on the regression model, supposed that farmers had no responsibility to their household members, or acting as household head only $\left(X_{1}\right.$ $=1)$; uneducated $(X 2=0)$; and no income $\left(X_{3}\right.$ $=0)$, then the consumption of HKm farmers was far greater than the consumption of the POF farmers, i.e. IDR 2,552,080/year and IDR $1,085,574 /$ year respectively or with the ratio of 2.35: 1.00. These figures asserted more strongly that limitation in access to natural resources provoked $\mathrm{HKm}$ farmers to meet their living needs by spending expenses as much as twice greater than that of POF farmers. The

Table 2. The summary of multiple linear regression analysis regarding households' consumption

\begin{tabular}{|c|c|c|c|c|}
\hline No. & Farmer Group & Regres & & $\begin{array}{l}\mathrm{R}^{2} \\
(\%)\end{array}$ \\
\hline 1. & $\mathrm{HKm}$ & $\begin{array}{l}\mathrm{Y}=1,638.256+868.823 .7 \mathrm{X} \\
\text { Significant Level }\end{array}$ & $\begin{array}{c}6.489 \mathrm{X}_{2}+0.705 \mathrm{X}_{3} \\
(0.23) \quad(0.00)\end{array}$ & 67.08 \\
\hline 2. & POF & $\begin{array}{l}\mathrm{Y}=288,044+797.529 \mathrm{X}_{1} \\
\text { Significant Level }\end{array}$ & $\begin{array}{l}420 \mathrm{X}_{2}+0.631 \mathrm{X}_{3} \\
(0.06) \quad(0.00)\end{array}$ & 70.39 \\
\hline
\end{tabular}

Remarks:

$\mathrm{Y}=$ Consumption by farmer households/(IDR per year); $\mathrm{X}_{1}=$ Household size (persons); $\mathrm{X}_{2}=$ The years of education (years); $\mathrm{X}_{3}=$ Incomes (IDR); ry.123 = Correlation coefficient 
ratio also indicated that such limitation for the $\mathrm{HKm}$ farmers was more severe than for the POF farmers. Such condition, therefore, it should overcome by providing HKm farmers with opportunities to develop alternative agriculture cultivation for their daily needs, or by introducing apiculture (honeybees on calliandra calothyrsus) to increase their incomes. This is by considering that calliandra trees can grow fast in almost any types of soils and at wide range of climate, including at the research location; and moreover, the market for bees honey was already available widely. Alternatively, government could encourage farmers to decrease their expenses for rice and tobacco by subsidising them with rain fed paddy and tobacco seeds which were suitable for local condition. The Virginia tobacco has been introduced in West Nusa Tenggara and these varieties have high yield and quality, less cost productions, uniform colour of mature leaf, and are able to grow well at extinction area (Suwarso et al., 2009).

Other potential commodity was cashew trees that grew widely, almost at any block on the research locations. However, the economic value of the abundance of cashew nut has not been utilized optimally. The farmers harvest only the nuts, and left the flesh of fruit. The flesh of fruit can actually be processed to become other valuable products such as chips or wine. Learning from this condition, provision of practical training related to food processing could be more profitable for the farmers. However, to make the economic value of the product works properly, the availability of market has to be facilitated by government. Agriculture sector could be a potential source of income to support expenditure for majority of persons $(48.4 \%)$ such as occurred in Zimbabwe (Zimbabwe National Statistics Agency, 2011).

Since consumption was viewed as a production activity and the household as a small firm, years of education could not significantly improve the productivity in this small firm (Juster, 1975). It was due to limited resources availability and lack of access to technology.

\section{Welfare Level of Farmer Households}

Welfare level of the farmers are necessarily assessed in order to obtain a figure of whether or not the development program set forth by the government was already accomplished evenly and enjoyed by the farmers. To examine the welfare indicators, this assessment used quantitative criteria, i.e. the so-called exchange value for the income earned by farmer households (EVIF). The EVIF value which was figured out from the earned incomes, expenses for consumption, and expenses for input production costs (on-farm and offfarm costs) could provide description about the welfare level which could be achieved by households (Table 3).

The values of EVIF which were calculated against the total expense for both farmer groups, each of them revealed the figure less than one $(\mathrm{EVIF}=0.74-0.99)$, indicating that all farmer groups at the research location still could not be categorized as prosperous in satisfying their subsistence needs. There was no difference on annual total consumption between the HKm farmers and the POF farmers, as shown in t-test in Table 4. This condition was also supported by Sajogyo (1997) who stated that poverty line was indicated by income per capita equivalent to exchange value of $320 \mathrm{~kg}$ rice/capita/year. As the price of rice per $\mathrm{kg}$ in research location was IDR 8,000 per $\mathrm{kg}$ and the size of households averagely 4 persons, the poverty line would fall on IDR $10,240,000$ per year. Although the income of POF farmers were much higher than the HKm farmers, however their total expense were also high. The average of land size managed by POF farmer was 1.75 ha which was higher than land size managed by $\mathrm{HKm}$ farmers (1.01 ha). According to Vidiawan and Tisnawati (2015), the welfare level could serve as one of the indicators associated with the development of poverty condition, in which the more decreasing the poverty level implied the more increasing the welfare of community would be.

Production costs expended by two farmer groups were low, and they considered that plant 
Table 3. Exchange value for the income earned by a farmer household per year at Labuhan Badas village

\begin{tabular}{lrr}
\hline & \multicolumn{2}{c}{ Farmers } \\
\cline { 2 - 3 } \multicolumn{1}{c}{ Descriptions } & $\begin{array}{r}\text { HKm } \\
\text { (IDR) }\end{array}$ & $\begin{array}{c}\text { POF } \\
\text { (IDR) }\end{array}$ \\
\cline { 2 - 3 } & $9,961,500$ & $19,625,000$ \\
\hline A. Incomes (I+II) & $3,531,500$ & $8,247,000$ \\
\hline I. Agriculture incomes & $2,622,500$ & $6,800,000$ \\
\hline 1. Agriculture Endeavours & 909,000 & $1,447,000$ \\
2. Farming labour wage & $6,430,000$ & $11,378,000$ \\
\hline II. Non-agriculture incomes & $6,430,000$ & $11,378,000$ \\
\hline 1. Non-agriculture endeavour & - & - \\
2. Non-agriculture labouring & $2,021,000$ & $3,105,000$ \\
\hline B. Production costs & 215,000 & $1,100,000$ \\
\hline 1. Agriculture & $1,806,000$ & $2,005,000$ \\
2. Non-agriculture & $11,369,600$ & $16,789,800$ \\
\hline C. Consumptions & $7,050,000$ & $11,703,000$ \\
\hline 1. Food & $4,319,600$ & $5,086,800$ \\
2. Non-food items & $13,390,600$ & $19,894,800$ \\
\hline D. Total expenses, Summation : B + C & & 6.32 \\
\hline E. Exchange value for incomes & 0.74 & 1.68 \\
\hline 1. Against the total expenses & 4.93 & 3.86 \\
2. Against the production cost & 1.41 & 1.17 \\
3. Against food consumption & 2.31 & \\
4. Against non-food consumption & 0.88 & \\
5. Against the total consumption & & \\
\hline Ren & & \\
\hline
\end{tabular}

Remarks: *) Figures at aspects A, B, C, and D in equivalent value to IDR

maintenance was still very limited. Moreover, they used seedlings taken from their own land; and the labours were taken from their own family, thereby rendering the production costs to be almost none. It was different from the consumption needs which should be available every day, therefore this induced farmers to make vigorous efforts to earn incomes, to meet their needs for food and non-food consumptions.

The expense by household could become a reliable measurement of their incomes, whereby the greater amount of expense for non-food items indicated that the more welfare of the living condition of those farmer household would be (Prasetyoningrum, Rahayu, \& Marwanti, 2016). Based on the EVIF analysis, the amount of income earned by the HKm farmers was still unable to meet their consumption necessities.
Current attempts done by those farmers to cope with their consumption needs were periodically migrating to Lombok to search additional incomes or borrowing money or items from the small shops or neighbours. If farmers borrowed money from the shops, they would pay back when their harvest came or the money was available. However, if they borrowed items (kitchen ingredients, rice, and other kinds of food) from their neighbours, they would seldom return it. This was because for $\mathrm{HKm}$ farmers, their neighbours were already regarded as closest relatives to share both difficulties and pleasures. This situation was in accordance with the statement from Zhao (2014) who said that rural household choose income diversification pattern by referring to the surrounding neighbourhood; when most farm families depended on off-farm activities to boost their 
Table 4. The result of $\mathrm{t}$ - test on annual total consumption between HKm farmer and POF farmer in Labuhan Badas village, Sumbawa.

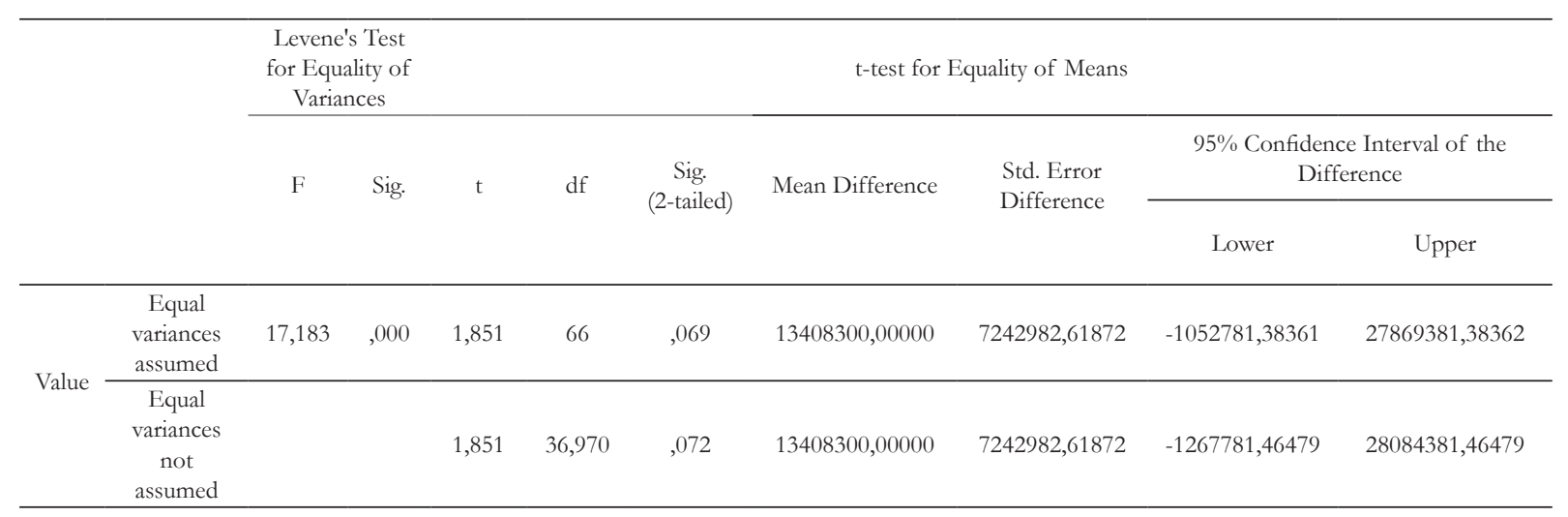

income, the individual household was more likely to follow the surrounding households by participating in the off-farm.

Such brotherhood sense presumably caused the HKm farmers to become more capable to solve their living difficulties. In addition, policy to provide incentives to the $\mathrm{HKm}$ farmers would seem to be easier to realize, because there is already a strong network, where their characters were more homogenous than the POF farmers. More importantly, the HKm as well as the POF farmers were potentially organized to contribute to the national food security programme by developing agroforestry system.

\section{CONCLUSION}

Findings of the research revealed that value of income strongly influenced the consumption of farmers living in the state production forest area (the community-based forest/the HKm) and the private owned forest (the POF) in rural Sumbawa. Size of household and years of education indicated the weaker affect to farmer consumption. The community-based forest farmers $(\mathrm{HKm})$ earned lower annual income than that of the private owned forest farmers. This condition combined with limited access to natural resources made the community-based forest farmers were unable to consume more varied food, and prefer to consume rice. It was due to rice that has been the only easiest carbohydrate sources to find in the state forest area either by cash or by borrowing from others.

To improve the welfare level of the two farmer types, there are two strategies that could be taken simultaneously by the farmers i.e. pressing the expenditure as well as improving the incomes. Both strategies were designed by prioritizing utilization of resources abundance of in their vicinity.

The expenditure of farmers could be decreased by reducing the amount spent for rice and for tobacco consumption. Government could support the farmer efforts by subsidizing them with rain fed paddy seeds and tobacco seeds of Virginia Hybrid varieties which are not only suitable for the West Nusa Tenggara climate but also produce high yield to meet high demand of cigarette industries. Meanwhile, income of the farmers could be increased by cultivating calliandra (Calliandra spp.) trees for developing apiculture and also utilize calliandra wood for wood charcoal or wood palled materials, which already has established market. Furthermore, the government has to facilitate training for the farmers on how to process the flesh of cashew fruit into products with higher economic value such as wine and chips. More importantly, the government should also develop further and generate new market to facilitate and simplify product marketing from the farmers. 


\section{ACKNOWLEDGEMENT}

The authors were gratefully indebted to the Institute for Research and Development on Agroforestry Technology, Ciamis which has financed these research activities. The authors also would like to convey a high appreciation to consecutively the Head and Staffs of Batulanteh's KPHP (Forestry Enterprising District), Sumbawa Regency, who have accompanied us when this research was carried out; the HKm and the privately owned forest farmers, who were all enthusiastically quite willing to follow the entire stages of research activities. Further appreciation was also extended to the forestry technicians for their valuable assistances in collecting the field data.

\section{REFERENCES}

Churchill, S. A., \& Farrell, L. (2017). Investigating the relationship between smoking and subjective welfare. Journal of Behavioral and ExperimentalEconomics, 71,1-12. doi:10.1016/j. socec.2017.08.003.

Crawford, I., Laisney, F., \& Preston, I. (2003). Estimation of household demand systems with theoretically compatible Engel curves and unit value specifications. Journal of Econometrics, 114(2), 221-241. doi:10.1016/ S0304-4076(03)00083-6.

Damora, A. S. U., Anwar, F., \& Heryatno, Y. (2008). Food consumption pattern of social forestry farmer household in West Lampung Regency. Jurnal Gizi dan Pangan, 3(3), 227-232.

Drewnowski, A., \& Specter, S. E. (2004). Poverty and obesity: The role of energy density and energy costs. The American Journal of Clinical Nutrition, 1(2), 6-16.

Foss, M. (2014). Access to state-owned forests critical for rural smallholders, study finds. Retrieved from http://blog.cifor.org/22245/accessto-state-owned-forests-critical-for-ruralsmallholders-study- finds\#.VFqmSTSsVI5 at 15 december 2017.

Hupkova', D., Bielik, P., \& Turcekova', N. (2009). Structural changes in the beef meat demand in Slovakia and demand elasticity estimation. Agricultural Economics, 55(8), 361-367.

Ibragimov, M. J., Ismagilov, I. I., \& Molotov, L. A. (2014). Income inequality in the Tatarstan. Kazan Economic Bulletin, 3(11), 67-73.

Jacobson, D., Mavrikiou, P. M., \& Minas, C. (2010). Household size, income and expenditure on food: The case of Cyprus. Journal of SocioEconomics, 39(2), 319-328. doi:10.1016/j. socec.2009.12.009.

Juster, F. T. (1975). Education, Income, and Human Behavior. NBER, 233-252. Retrieved from http://www.nber.org/books/just75-1 at 20 December 2017

Kedir, A. M., \& Sookram, S. (2011). Poverty and welfare of the poor in a high-income country: Evidence from Trinidad and Tobago. Journal of International Development, 5(4),520-535. doi:10.1002/jid.1824.

Larsen, E. R. (2007). Does the CPI mirror the cost of living? Engel's law suggests not in Norway. Scandinavian Journal of Economics, 109(1), 177195.

Misbahuddin, \& Hasan, I. (2013). Analisis data penelitian dengan statistik. Jakarta: PT. Bumi Asara.

Morgan, G. A., \& Harmon, R. J. (2001). Clinicians' guide to research methods and statistics : data collection techniques. Journal of the American Academy of Child and Adolescent Psychiatry, 40(8).

Ningsih, M., Suandi, \& Damayanti, Y. (2012). Faktor-faktor yang Mempengaruhi Pola Konsumsi Pangan dan Gizi Rumah Tangga Nelayan Kecamatan Tungkal Ilir . Jurnal Sosio Ekonomika Bisnis, 15(1), 48-56.

Palys, T. (2008). Purposive sampling. In L. Given (Ed.), The sage enscylopedia of qualitative research methods (2 $2^{\text {nd }}$ ed.), (pp. 297-298). Los Angeles: Sage.

Prasetyoningrum, F., Rahayu, E. S., \& Marwanti, S. (2016). Analisis pola konsumsi rumah tangga petani jagung di Kabupaten Grobogan. Agric Jurnal Ilmu Pertanian, 28(1), 41-54.

Purwantini, T. B. (2012). Analisis dinamika konsumsi pangan dan kesejahteraan rumah tangga petani padi. Prosiding Litbang Pertanian, 
508-522. Bogor: Pusat Sosial Ekonomi dan Kebijakan Pertanian.

Pusposari, F. (2012). Analisis pola konsumsi pangan masyarakat di Provinsi Maluku. Universitas Indonesia, Jakarta.

Randy, R. S., Rudi, H., \& Herwanti, S. (2016). Analisis pendapatan dan kesejahteraan petani agroforestri dikelurahan Sumber Agung kecamatan Kemiling Kota Bandar Lampung. Jurnal Sylva Lestari, 4(2), 17-26.

Sosa, M., Cardinal, P., Contarini, A., \& Hough, G. (2015). Food choice and emotions: Comparison between low and middle income populations. Food Research International, 76(P2), 253-260. doi:10.1016/j.foodres.2014.12.031.

Srivastava, D., \& McGuire, A. (2015). Patient access to health care and medicines across lowincome countries. Social Science \& Medicine, 133, 21-27. doi:10.1016/j.socscimed.2015.03.021.

Sugiyono. (2013). Metode penelitian kuantitatif, kualitatif dan R\&D. Bandung: Alfa Beta CV.

Suwarso, Herwati, A., Murdiyati, A. S., Deciyanto, S., Santoso, I., Haryanto, D., ... Pambudi, D. (2009). Potensi tembakau Virginia Flue Cured Varietas NC 100 di Lombok. Buletin Tanaman Tembakau, Serat \& Minyak Industri, 1(1), 1-9.

Tomek, W. G., \& Kaiser, H. . (2014). Agricultural product prices. Itacha and London: Cornel University Press.

Vidiawan, E., \& Tisnawati, N. M. (2015). Household consumption at Batu Kandik village, Nusa Analisis Pengaruh pendapatan jumlah anggota keluarga dan pendidikan terhadap konsumsi keluarga miskin. Ekonomi Pembangunan Universitas Udayana, 4(4), 243-257.
Widome, R., Joseph, A. M., Hammett, P., Van Ryn, M., Nelson, D. B., Nyman, J. A., \& Fu, S. S. (2015). Associations between smoking behaviors and financial stress among lowincome smokers. Preventive Medicine Reports, 2, 911-915. doi:10.1016/j.pmedr.2015.10.011.

Yulian, R., Hilmanto, R., \& Herwanti, S. (2016). Exchange Household income of agroforestry farmers at bina wana jaya I community forest protection forest management unit of Batultegi Tanggamus District. Jurnal Sylva Lestari, 4(2), 39-50.

Zentková, I., \& Hošková, E. (2011). The influence of the Slovak household income differentiation on food expenditures - The Engel's expenditures functions estimation. Agricultural Economics, 57(11), 534-544.

Zhao, J. (2014). Rural income diversification patterns and their determinants in China. Agricultural Economics, 60(5), 219-231.

Zimbabwe National Statistics Agency. (2011). Poverty income consumption and expenditure survey. Retrieved from http://www.zimstat. co.zw/dmdocuments/Finance/Poverty2011. pdf at 6 January 2018. 